\title{
Expressions of Children and Families on Children's Rights: Lessons from STM: EC 2019
}

\author{
Warda Batool \\ Marina Apostolopoulos \\ Melissa Bagirakandi \\ Nichola Nonis Jayawardena \\ Justine Lee \\ Graduate Students in Early Childhood Studies, Ryerson University \\ Toronto, Ontario
}

\begin{abstract}
The Shaking the Movers: Early Childhood (STM: EC) event was held at Ryerson University in Toronto on April 6 ${ }^{\text {th }}, 2019$ and was the first in the Shaking the Movers Workshop Series to invite young children to participate in learning about and discussing their inherent rights. In this article, five graduate students draw on young children's and family members' expressions, with regard to children's right to non-discrimination (United Nations General Assembly, 1989, Article 2), as well as lessons learned, and their suggestions for future STM events. Children's and families' experiences as presented in the STM: EC report (Robichaud et al., 2019) were examined and the following themes emerged: children's ideas and thoughts about their rights, spaces for children to learn about their rights, and adults' views and ideas about children's rights. The authors provide evidence on how events such as STM are beneficial in understanding children's expressions and ideas regarding their rights, and the importance of creating spaces that foster awareness on children's rights.
\end{abstract}

Keywords: Shaking the Movers, children's rights, right to non-discrimination, children's expression, early childhood education 


\section{Introduction}

Canada ratified the United Nations Convention on the Rights of the Child (UNCRC) in 1991 (United Nations Human Rights, 2019). However, children's rights have been a topic of discussion since the late 20th century and have gradually gained prominence. Children's rights advocates have been creating spaces that invite children to discuss their ideas, experiences, and suggestions in relation to their rights. The Landon Pearson Centre for the Study of Childhood and Children's Rights (LPC) initiated and designed annual Shaking the Movers (STM) events for youth across Canada which are specifically focused on youth-led learning about rights documented in the UNCRC and what children think and understand about their rights (Pearson \& Collins, 2011). Initially, LPC's design for STM did not include younger children. However, the present article will focus on an event that was designed to include younger children and therefore, it will provide a different perspective. STM follows a rights-based approach and a participatory model as families and children are invited to participate and youth are invited to volunteer. Following a rights-based approach, principles of children's rights are integrated throughout the planning and implementation of STM events.

The planning, facilitation, and debriefing of the Shaking the Movers event was an assignment in partial completion of the Children's Rights course offered in the Master of Arts in Early Childhood Studies program at Ryerson University (RU). The authors of this article collaborated with their classmates and planned the STM: Early Childhood (STM: EC) event that took place on April 6, 2019. The graduate students planned and facilitated activities related to children's right to non-discrimination for children between the ages of 4- to 10-years-old and their families. Using our learnings and documentation from the event, we further explored STM: EC. In this article, we highlight the following major themes related to children's rights: understanding children's ways of expressing their rights awareness, spaces for fostering the right for children to learn about their rights, and families' beliefs and ideas with respect to children's rights. We also suggest recommendations for future STM events and how we can continue to create spaces that encourage opportunities for children to express their thoughts and ideas about their rights. Based on children's expressions and their understanding of rights, our recommendations include using outdoor spaces for activities, rethinking children's means of expression and providing the adequate resources for expression to take place. 


\section{Children's Rights Beyond Educational Spaces}

The UNCRC states that all children, young people and adults should know about the Convention (Article 42). They should also know that their rights are promoted and respected (Howe \& Covell, 2007). When adults contribute to the development of such spaces and work together with children to explore their rights, it portrays the message that both adults and children are actively promoting and respecting children's rights. In adopting this collaborative approach, children may come to view adults as allies, as opposed to authority figures to whom they must answer. Children spend a significant portion of their time in early learning programs, therefore, their early learning environment is an ideal site where they learn about and realize their rights. However, providing spaces and opportunities for children to explore children's rights independent of the education system goes beyond fulfilling a child's right to know. It also helps them learn about what they can do to respect the rights of others. The STM: EC event provides an example of a space open to the public, where children can explore their rights (Robichaud et al., 2019). Offering the event at an early learning setting (i.e., Ryerson's Early Learning Centre), was an intentional decision as we wanted to provide children with a sense of familiarity and safety by being in a classroom setting. Future events may want to consider exploring spaces such as parks to eliminate a classroom-like atmosphere and to emphasize that learning about rights can occur elsewhere.

Young children should not be dismissed when it comes to fostering spaces for children to know about their rights. The STM: EC event illustrates that when children are provided with a safe and comfortable space where they are treated fairly and accepted as capable, competent actors, they demonstrate that they are not too young to express, explore and learn about their fundamental rights. For instance, the 4- to 5-year-old children were offered supplies (paper, various art materials including playdough and plasticine) to express what rights mean to them. One child chose plasticine to express their right to play while another drew their right to sleep (Robichaud et al., 2019). These and many other examples from the workshop convey that young children are capable of forming views about their rights and are competent to express those views in regard to their rights (United Nations General Assembly, 1989, Article 12). 


\section{Children's Views on Decision-Making}

Decision-making around early learning and curriculum could take advantage of children's perspectives. Schools that have adopted a rights-based approach to their classroom practices, policies and curriculum, also known as "Rights Respecting Schools (RRS), exemplify the value of implementing a school philosophy that reflects children's rights (Dunhill, 2018; Sebba \& Robinson, 2010). RRS is an initiative by the United Nations International Children's Emergency Fund (UNICEF) and uses the UNCRC as a framework to help shape a school culture that reflects respect for oneself and others, inclusion and empowerment (UNICEF, 2013). This program demonstrates that children acknowledge that they are rights-holders but also that they play an active role in upholding these rights (Dunhill, 2018). Sebba and Robinson (2010) found that there was a decline in bullying in RRS schools and Dunhill (2018) found that children who learned about human rights were encouraged to promote them beyond their classrooms.

According to the UNCRC, children should play an active role in applying rules and policies by participating in both the creation and implementation of decisions (UNCRC Article 12). These practices have shown positive effects on children's behaviour and less burnout for teachers (Covell, McNeil, \& Howe, 2009). The RSS researchers reported that student participation and rights-respecting behaviour positively impacted the teacher's relationships with their students and led them to feel more effective in their role. Moreover, tchildren's behaviour improved due to increased participation and school engagement which was supported by a children's rights framework (Covell et al., 2009). Early childhood education and care centres are a hub for learning and exploring; thus, integrating children's rights in programming should not be limited to formal education as learning occurs in spaces outside of formal schooling.

\section{Shaking the Movers: Early Childhood 2019 (STM:EC)}

Shaking the Movers (STM) workshops are youth-led and youth-driven annual workshops that invite children and youth to safely discuss and celebrate their views, experiences, and suggestions around their rights as children. Workshops are youth facilitated and are held across Canada. The STM: EC 2019 event was part of a pilot project to include younger groups of children and showcase the importance of hearing from younger children on their civil and political rights. 
Each year the major theme of the event is focused on a specific children's rights topic chosen by the participating youth (Pearson \& Collins, 2011). STM workshops invite children to express their autonomy and encourage them to utilize their agency to make meaning of their reallife experiences (Robichaud et al., 2019).

Graduate students in the Master of Arts Early Childhood Studies (MA ECS) program at RU were enrolled in a Children's Rights course. The course instructor, Dr. Aurelia Di Santo, designed an assignment based on the STM model. The assignment required students to plan activities for the workshop based on children's right to non-discrimination (UNCRC Article 2). The MA students also trained youth facilitators from the community to lead those activities with the participating children. Each group of six to seven MA ECS students chose an age group (4to 5-year-olds, 6- to 8-year-olds, 9- to 10-year-olds), or a family group (this included the families of the children involved in the workshop), and were responsible for planning the activities for their group. The one day event was held in RU's lab school, the Early Learning Centre.

The day was divided into two sections. The morning consisted of training the youth facilitators, two of whom were first-year students in the Early Childhood Studies program at RU, and included discussing the planned activities. Each group of students also presented their workshop ideas to the youth facilitators and special guests who had been invited to attend the workshops; they included the Honorable Landon Pearson, Dr. Tricia Lirette (MacEwan University), Brittany Aamot (Senior Manager of Early Learning at MacEwan Childcare Centre), and Tara Stang (Senior Program Officer of the Muttart Foundation). The afternoon consisted of coordinating the arrival of the families and facilitating the workshops. Each group had designated note-takers and photographers. One graduate student in each group was designated the "helper" and wore a red clothing item. The "helper" was introduced to the children as the person they could reach out to if they needed anything (e.g., needing quiet time, wanting to be reunited with their family members). The notes and photographs gathered from all the notetakers and students' reflections contributed to the final STM: EC report. This event was one of the first STM events to include young children and demonstrated the value that is placed on the importance of listening to, acknowledging, and appreciating what children of all ages have to say about their rights. 


\section{Shaking The Movers: Early Childhood Planning Process}

Students in the MA ECS program made an active effort during the planning process to mitigate the power imbalance between adults and children from inception to completion. We challenged the status quo by eliminating one-directional learning in order to implement activities that focused on children's right to non-discrimination and to mitigate the power imbalance between adults and children. As children were not familiar with the environment, we implemented strategies to ensure a welcoming environment. For example, upon sign in, each child had the opportunity to sit down with a graduate student to speak and gain information about the workshop before they assented to participating. Children were also invited to choose whether or not they would like their picture taken.

The graduate students intentionally planned to omit top-down teaching tendencies in order to take a rights-based approach to learning. For instance, an activity for the 4- to 5-yearold children included reading the book I Have the Right to Be a Child (Serres, 2009). A youth facilitator posed questions throughout the reading to encourage discussion and children's exploration of rights. To create a sense of safety and comfort, children were invited to "express their views without fear of rebuke or reprisal," (Robinson, 2011, p. 440). For instance, they were not expected to raise their hand in order to speak; rather, they were encouraged to comment whenever they pleased. In addition, the youth facilitator sat on the carpet at the children's eyelevel instead of sitting on a chair that would have placed them physically above the children. Sitting on a chair provides the facilitator with a higher view of the children and ultimately implies a power imbalance. As the facilitator looks down at the children, they assert their status as being more powerful. During the planning stage, the students planned to facilitate the reading activity by presenting it on a projector and having a question and answer period with the children. However, upon reflection, they thought about what it means to implement a rightsbased approach and realized that this activity demonstrated adult power; thus, they re-designed the activity to mitigate such a dynamic.

The graduate students also applied strategies to encourage the youth facilitators to take the lead with several of the activities. We started by introducing ourselves and inviting youth facilitators to share their ideas about how to lead the activities. Youth facilitators chose roles based on their interest and/or skill. For example, one youth facilitator stated that they were most comfortable with and interested in reading a story and facilitating the discussion. Placing priority 
on youth-led activities was the graduate students' attempt to create an inclusive environment where everyone was welcomed to participate and to share the decision-making with the youth facilitators.

The fact that planning a rights-based event proved to be challenging for some of the graduate students speaks to the general lack of rights-based courses in learning environments.

The STM: EC event highlights that learning environments that are underpinned by a rights-based approach are possible and can be successful. Ultimately, this calls attention to the implementation of a rights-based philosophy that must occur at all levels of education, including early childhood education, and that is also integrated in policies and curricula.

\section{UNCRC Article 2: The Right to Non-Discrimination}

The STM: EC event was structured around the right to non-discrimination (UNCRC Article 2). All children were invited to participate, regardless of their gender, race, class, ethnicity, ability, sexuality and locality. In support of children's right to non-discrimination, the STM: EC event exhibited that adults and children are capable of working in unison to discuss and apply appropriate measures in addressing issues that pertain to children and their rights. Moreover, the event recognized and respected the rights of every child and ensured that they were upheld from the moment of planning and organization to the implementation of the event. Through intensive class discussions and readings about the UNCRC, the graduate students were knowledgeable about children's rights and critically evaluated their activities and programming of the STM: EC event prior to implementation.

The STM: EC event at RU was one of the first of three pilot workshops to include young children, the two other events held in Pond Inlet and Edmonton. All three workshops set an example for future event coordinators to understand that age and socially perceived levels of maturity must not be a source of discrimination for participating in events. In denoting age and maturity as criteria for participation, children are discriminated against based on their level of competence measured according to the standards of adults (Stoecklin, 2013). Paradoxically, children's participation becomes conditional and the inherent goal of viewing children as equal participatory bodies becomes diminished (Shier, 2010). As stated by Stoecklin (2013), 'being competent' refers to the ways in which competence and maturity are recognized according to relevant social constructs. It should be acknowledged that children exercise their autonomy to 
varying degrees that are characteristically dependent on the course of their development (Stoecklin, 2013). As the UNCRC suggests, children have evolving capacities and it is the duty of parents, legal guardians, and the state to enable children in exercising those capacities (UNCRC Article 14). The STM: EC event made this idea evident as young children were capable of expressing their views about their rights in varying ways. Additionally, it embraced the idea that age is a cultural construct and that we must work toward a cultural change that closely connects age to participation and decision making (Lansdown, Jimerson, \& Shahroozi, 2014).

\section{Children's Expressions of Rights Awareness}

In understanding what children might share about the topic of the right to nondiscrimination (UNCRC Article 2), we had to also think about the right to form his/her views and the right to express those views (UNCRC Article 12). Expressions are most commonly understood through verbal language or explicit behaviour. However, what if the expression is not verbal or explicit? From the STM: EC event we learned that many of the children's understandings of rights were not explicit, however, their expressions held deeper meanings (Robichaud et al., 2019). Therefore, it is important to think about how children express their views and ideas in practice. What forms can expression take? How can adults recognize children's implicit ways of expressing their ideas? For adults interacting with children it would be significant and beneficial to reflect on one's understanding of how children choose to express themselves. Moreover, it would be beneficial for adults to reflect on their ideas and think about potential biases that may not align with how children may want to express their perspectives and experiences in relation to their rights. This is significant because it invites children to form and express their views in their own unique way that is not adult controlled and monitored. It also encourages adults to acknowledge those views and give them due weight.

In order to further explore children's expressions of their rights, we share children's views and examples of the ways in which they shared their ideas related to their right to nondiscrimination. We analyzed children's quotes from the STM: EC report and the reflections of three graduate students who were involved in the event to highlight the ways in which children expressed their understanding of rights. It is important to note that our interpretations are through an adult lens; therefore, one must consider the potential for bias. Children's experiences during 
the workshops also informed the recommendations for future STM workshops for young children.

Table 1 presents examples of children's ideas and the corresponding rights. Table 2 presents children's nonverbal expressions and the corresponding rights.

Table 1: Children's Ideas and the Corresponding Rights

\begin{tabular}{|c|c|}
\hline Children's Ideas & Children's Rights \\
\hline $\begin{array}{l}\text { During an activity where children } \\
\text { were asked about needs } \\
\text { "We need to be kind" T, } 4\end{array}$ & $\begin{array}{l}\text { Article 2: States Parties shall respect and ensure the } \\
\text { rights set forth in the present Convention to each child } \\
\text { within their jurisdiction without discrimination of any } \\
\text { kind, irrespective of the child's or his or her parent's or } \\
\text { legal guardian's race, colour, sex, language, religion, } \\
\text { political or other opinion, national, ethnic or social } \\
\text { origin, property, disability, birth or other status. } \\
\text { 2. States Parties shall take all appropriate measures to } \\
\text { ensure that the child is protected against all forms of } \\
\text { discrimination or punishment on the basis of the status, } \\
\text { activities, expressed opinions, or beliefs of the child's } \\
\text { parents, legal guardians, or family members. }\end{array}$ \\
\hline $\begin{array}{l}\text { When asked what can we do to } \\
\text { stand up for our rights } \\
\text { "Say Something." } \\
\text { We should help them, stand up for } \\
\text { them, and make them feel better." } \\
\text { V, } 10\end{array}$ & $\begin{array}{l}\text { Article 12: The right to forming his or her own views and } \\
\text { the right to express those views freely in all matters } \\
\text { affecting the child. } \\
\text { 1.State Parties shall assure to the child who is capable of } \\
\text { forming his or her own views the right to express those } \\
\text { views freely in all matters affecting the child, the views } \\
\text { of the child being given due weight in accordance with } \\
\text { the age and maturity of the child } \\
\text { 2.For this purpose, the child shall in particular be } \\
\text { provided the opportunity to be heard in any judicial and } \\
\text { administrative proceedings affecting the child, either } \\
\text { directly or through a representative or an appropriate } \\
\text { body, in a manner consistent with the procedural rules of } \\
\text { national law }\end{array}$ \\
\hline
\end{tabular}




\begin{tabular}{|c|c|}
\hline $\begin{array}{l}\text { When asked to draw what you } \\
\text { learned about your rights } \\
\text { "Stand up for our friends." }\end{array}$ & $\begin{array}{l}\text { Standing up for your rights and your friends could mean } \\
\text { you are willing to challenge violations of rights. }\end{array}$ \\
\hline $\begin{array}{l}\text { When discussing needs } \\
\text { "It's healthy and you don't want to } \\
\text { get hungry or sick." R, } 4 \\
\text { "Food. You don't have energy and } \\
\text { you get hungry." R, } 5 \\
\text { When asked to think about the } \\
\text { sentence, "I have a right to..." } \\
\text { T, } 4 \text { drew a date (the fruit) but } \\
\text { shared that he doesn't like dates. } \\
\text { When asked if it's a want or a need } \\
\text { he responded: "A want! No! A } \\
\text { need!" T. drew the date as he } \\
\text { believes they are a need because } \\
\text { they are food. }\end{array}$ & $\begin{array}{l}\text { Articles } 24 \text { : The right to the highest attainable standard of } \\
\text { health. } \\
\text { 1. States Parties recognize the right of the child to the } \\
\text { enjoyment of the highest attainable standard of health and } \\
\text { to facilities for the treatment of illness and rehabilitation } \\
\text { of health. States Parties shall strive to ensure that no child } \\
\text { is deprived of his or her right of access to such health } \\
\text { care services. } \\
\text { 2. States Parties shall pursue full implementation of this } \\
\text { right and, in particular, shall take appropriate measures: } \\
\text { (a) To diminish infant and child mortality; } \\
\text { (b) To ensure the provision of necessary medical } \\
\text { assistance and health care to all children with emphasis } \\
\text { on the development of primary health care; } \\
\text { (c) To combat disease and malnutrition, including within } \\
\text { the framework of primary health care, through, inter alia, } \\
\text { the application of readily available technology and } \\
\text { through the provision of adequate nutritious foods and } \\
\text { clean drinking-water, taking into consideration the } \\
\text { dangers and risks of environmental pollution; } \\
\text { (d) To ensure appropriate prenatal and postnatal health } \\
\text { care for mothers; } \\
\text { (e) To ensure that all segments of society, in particular } \\
\text { parents and children, are informed, have access to } \\
\text { education and are supported in the use of basic } \\
\text { knowledge of child health and nutrition, the advantages } \\
\text { of breastfeeding, hygiene and environmental sanitation } \\
\text { and the prevention of accidents; } \\
\text { (f) To develop preventive health care, guidance for } \\
\text { parents and family planning education and services. } \\
3 . \text { States Parties shall take all effective and appropriate } \\
\text { measures with a view to abolishing traditional practices } \\
\text { prejudicial to the health of children. } \\
\text { 4. States Parties undertake to promote and encourage } \\
\text { international co-operation with a view to achieving }\end{array}$ \\
\hline
\end{tabular}


progressively the full realization of the right recognized in the present article. In this regard, particular account shall be taken of the needs of developing countries.

Article 27: 1. States Parties recognize the right of every child to a standard of living adequate for the child's physical, mental, spiritual, moral and social development. 2. The parent(s) or others responsible for the child have the primary responsibility to secure, within their abilities and financial capacities, the conditions of living necessary for the child's development.

3. States Parties, in accordance with national conditions and within their means, shall take appropriate measures to assist parents and others responsible for the child to implement this right and shall in case of need provide material assistance and support programmes, particularly with regard to nutrition, clothing and housing.

4. States Parties shall take all appropriate measures to secure the recovery of maintenance for the child from the parents or other persons having financial responsibility for the child, both within the State Party and from abroad. In particular, where the person having financial responsibility for the child lives in a State different from that of the child, States Parties shall promote the accession to international agreements or the conclusion of such agreements, as well as the making of other appropriate arrangements.

The right to safe/healthy food.

The importance of good food for wellbeing and health. The realization that rights are for everyone.

Although someone may not like a particular food, it does not mean that it should not be considered a need. 


\begin{tabular}{|c|c|}
\hline $\begin{array}{l}\text { When asked if a dog is a "want" } \\
\text { or a "need" } \\
\text { "Because we need dogs sometimes } \\
\text { like a rescue dog." R, } 5\end{array}$ & $\begin{array}{l}\text { Article 23:1. States Parties recognize that a mentally or } \\
\text { physically disabled child should enjoy a full and decent } \\
\text { life, in conditions which ensure dignity, promote self- } \\
\text { reliance and facilitate the child's active participation in } \\
\text { the community. } \\
\text { 2. States Parties recognize the right of the disabled child } \\
\text { to special care and shall encourage and ensure the } \\
\text { extension, subject to available resources, to the eligible } \\
\text { child and those responsible for his or her care, of } \\
\text { assistance for which application is made and which is } \\
\text { appropriate to the child's condition and to the } \\
\text { circumstances of the parents or others caring for the } \\
\text { child. } \\
\text { Possible understanding that accommodations and } \\
\text { protection are needs based. Need for rescue/service dog. }\end{array}$ \\
\hline $\begin{array}{l}\text { When shown a picture of dirty } \\
\text { water and asked if it is a need } \\
\text { "Because you don't need it 'cause } \\
\text { it's dirty." R, } 4 \\
\text { "Because dirty water can make } \\
\text { you die." R, } 5 \\
\text { When asked to think about the } \\
\text { sentence, "I have a right to..." } \\
\mathrm{R}, 4 \text { drew water for his dinosaur } \\
\text { because water is a need. }\end{array}$ & Article 24: see note above \\
\hline $\begin{array}{l}\text { During a discussion about what it } \\
\text { feels like to be different } \\
\text { "Some people might want to be } \\
\text { other people, but we should all be } \\
\text { ourselves." V, } 10\end{array}$ & $\begin{array}{l}\text { Article } 8: 1 \text {. States Parties undertake to respect the right of } \\
\text { the child to preserve his or her identity, including } \\
\text { nationality, name and family relations as recognized by } \\
\text { law without unlawful interference. } \\
2 \text {. Where a child is illegally deprived of some or all of the } \\
\text { elements of his or her identity, States Parties shall } \\
\text { provide appropriate assistance and protection, with a } \\
\text { view to re-establishing speedily his or her identity. } \\
\text { Celebration of difference. Challenging assimilation and } \\
\text { encouraging the ownership of one's own identity and } \\
\text { uniqueness. }\end{array}$ \\
\hline
\end{tabular}




\begin{tabular}{|c|c|}
\hline $\begin{array}{l}\text { When invited to draw a } \\
\text { representation of themselves and } \\
\text { their understanding of the right to } \\
\text { non-discrimination } \\
\text { "Nice or poor doesn't matter." E, } \\
10 \\
\text { "Children are diamonds. Don't } \\
\text { carve them." M, } 11\end{array}$ & Article 2: See note above \\
\hline $\begin{array}{l}\text { When talking about happiness } \\
\text { "When I'm with my sister." N, } 5 \\
\text { "I feel happy at home when I'm } \\
\text { with my family." B, } 5 \\
\text { "When I'm spending it with my } \\
\text { mommy." A, } 4 \\
\text { When shown a "need" sign and } \\
\text { asked what is a need } \\
\text { "parents" N, } 5 \\
\text { When creating rights puzzles and } \\
\text { thinking about the sentence, "I } \\
\text { have a right to..." } \\
\text { "My mom and dad." } \\
\text { "Live in a home." } \\
\text { After reading the book Say } \\
\text { Something (Reynolds, 2019), } \\
\text { children were asked, "Who can we } \\
\text { say something to" if we are } \\
\text { discriminated } \\
\text { Children replied, "Trusted family." } \\
\text { "Adults." "Friends." "Teachers." }\end{array}$ & $\begin{array}{l}\text { Article } 7: \text {. The child shall be registered immediately } \\
\text { after birth and shall have the right from birth to a name, } \\
\text { the right to acquire a nationality and. as far as possible, } \\
\text { the right to know and be cared for by his or her parents. } \\
\text { Article 9: } 1 . \text { States Parties shall ensure that a child shall } \\
\text { not be separated from his or her parents against their will, } \\
\text { except when competent authorities subject to judicial } \\
\text { review determine, in accordance with applicable law and } \\
\text { procedures, that such separation is necessary for the best } \\
\text { interests of the child. Such determination may be } \\
\text { necessary in a particular case such as one involving abuse } \\
\text { or neglect of the child by the parents, or one where the } \\
\text { parents are living separately and a decision must be made } \\
\text { as to the child's place of residence. } \\
\text { 2. In any proceedings pursuant to paragraph } 1 \text { of the } \\
\text { present article, all interested parties shall be given an } \\
\text { opportunity to participate in the proceedings and make } \\
\text { their views known. } \\
\text { 3. States Parties shall respect the right of the child who is } \\
\text { separated from one or both parents to maintain personal } \\
\text { relations and direct contact with both parents on a regular } \\
\text { basis, except if it is contrary to the child's best interests. } \\
4 \text {. Where such separation results from any action initiated } \\
\text { by a State Party, such as the detention, imprisonment, } \\
\text { exile, deportation or death (including death arising from } \\
\text { any cause while the person is in the custody of the State) } \\
\text { of one or both parents or of the child, that State Party } \\
\text { shall, upon request, provide the parents, the child or, if } \\
\text { appropriate, another member of the family with the }\end{array}$ \\
\hline
\end{tabular}




\begin{tabular}{|c|c|}
\hline & $\begin{array}{l}\text { essential information concerning the whereabouts of the } \\
\text { absent member(s) of the family unless the provision of } \\
\text { the information would be detrimental to the well-being of } \\
\text { the child. States Parties shall further ensure that the } \\
\text { submission of such a request shall of itself entail no } \\
\text { adverse consequences for the person(s) concerned. } \\
\text { Article 5: State Parties shall respect the responsibilities, } \\
\text { rights and duties of parents or, where applicable, the } \\
\text { members of the extended family or community as } \\
\text { provided for by local custom, legal guardians or other } \\
\text { persons legally responsible for the child, to provide, in a } \\
\text { manner consistent with the evolving capacities of the } \\
\text { child, appropriate direction and guidance in the exercise } \\
\text { by the child of the rights recognized in the present } \\
\text { Convention. } \\
\text { Having people to protect our rights is a need. } \\
\text { Family, adults, friends, and teachers are rights protectors. }\end{array}$ \\
\hline $\begin{array}{l}\text { When talking about happiness } \\
\text { "When I'm outside." T, } 4 \\
\text { "I'm happy ... when I'm outside." } \\
\text { T, } 4 \\
\text { "Watch TV." } \\
\text { "I feel happy when I play my ninja } \\
\text { game." Z, } 4 \\
\text { When creating responses to the } \\
\text { sentence, "I have a right to..." } \\
\text { R, } 4 \text { chose plasticine to express his } \\
\text { right to play. } \\
\mathrm{N}, 5 \text { drew that she "has a right to } \\
\text { sleep!" } \\
\text { B, } 5 \text { said that she has a right to } \\
\text { play, "I am drawing two friends." }\end{array}$ & $\begin{array}{l}\text { Article } 31: \text {. States Parties recognize the right of the } \\
\text { child to rest and leisure, to engage in play and } \\
\text { recreational activities appropriate to the age of the child } \\
\text { and to participate freely in cultural life and the arts. } \\
\text { 2. States Parties shall respect and promote the right of the } \\
\text { child to participate fully in cultural and artistic life and } \\
\text { shall encourage the provision of appropriate and equal } \\
\text { opportunities for cultural, artistic, recreational and leisure } \\
\text { activity. } \\
\text { Article 24: See note above }\end{array}$ \\
\hline
\end{tabular}

Source: (Robichaud et al., 2019) 
Table 2: Children's Nonverbal Expressions and the Corresponding Rights

\begin{tabular}{|c|c|}
\hline Children's Nonverbal Expressions & Children's Rights \\
\hline $\begin{array}{l}\text { When entering and exploring RU's Early } \\
\text { Learning Centre } \\
\text { Smiling at art pieces, pictures and } \\
\text { resources. } \\
\text { Exploring the toys in the early learning } \\
\text { room. } \\
\text { Laughter. }\end{array}$ & $\begin{array}{l}\text { Article } 3 \text { : } 1 \text {. In all actions concerning children, } \\
\text { whether undertaken by public or private social } \\
\text { welfare institutions, courts of law, } \\
\text { administrative authorities or legislative bodies, } \\
\text { the best interests of the child shall be a primary } \\
\text { consideration. } \\
\text { 2. States Parties undertake to ensure the child } \\
\text { such protection and care as is necessary for his } \\
\text { or her well-being, taking into account the rights } \\
\text { and duties of his or her parents, legal guardians, } \\
\text { or other individuals legally responsible for him } \\
\text { or her, and, to this end, shall take all } \\
\text { appropriate legislative and administrative } \\
\text { measures. } \\
3 . \text { States Parties shall ensure that the } \\
\text { institutions, services and facilities responsible } \\
\text { for the care or protection of children shall } \\
\text { conform with the standards established by } \\
\text { competent authorities, particularly in the areas } \\
\text { of safety, health, in the number and suitability } \\
\text { of their staff, as well as competent supervision. } \\
\text { Feelings of safety and comfort. }\end{array}$ \\
\hline $\begin{array}{l}\text { Conversing with youth facilitators, } \\
\text { graduate students, and/or family members } \\
\text { about activities, their rights drawings, and } \\
\text { about the event. }\end{array}$ & $\begin{array}{l}\text { Article 12: 1. States Parties shall assure to the } \\
\text { child who is capable of forming his or her own } \\
\text { views the right to express those views freely in } \\
\text { all matters affecting the child, the views of the } \\
\text { child being given due weight in accordance } \\
\text { with the age and maturity of the child. } \\
\text { 2. For this purpose, the child shall in particular } \\
\text { be provided the opportunity to be heard in any } \\
\text { judicial and administrative proceedings } \\
\text { affecting the child, either directly, or through a } \\
\text { representative or an appropriate body, in a } \\
\text { manner consistent with the procedural rules of } \\
\text { national law. }\end{array}$ \\
\hline
\end{tabular}




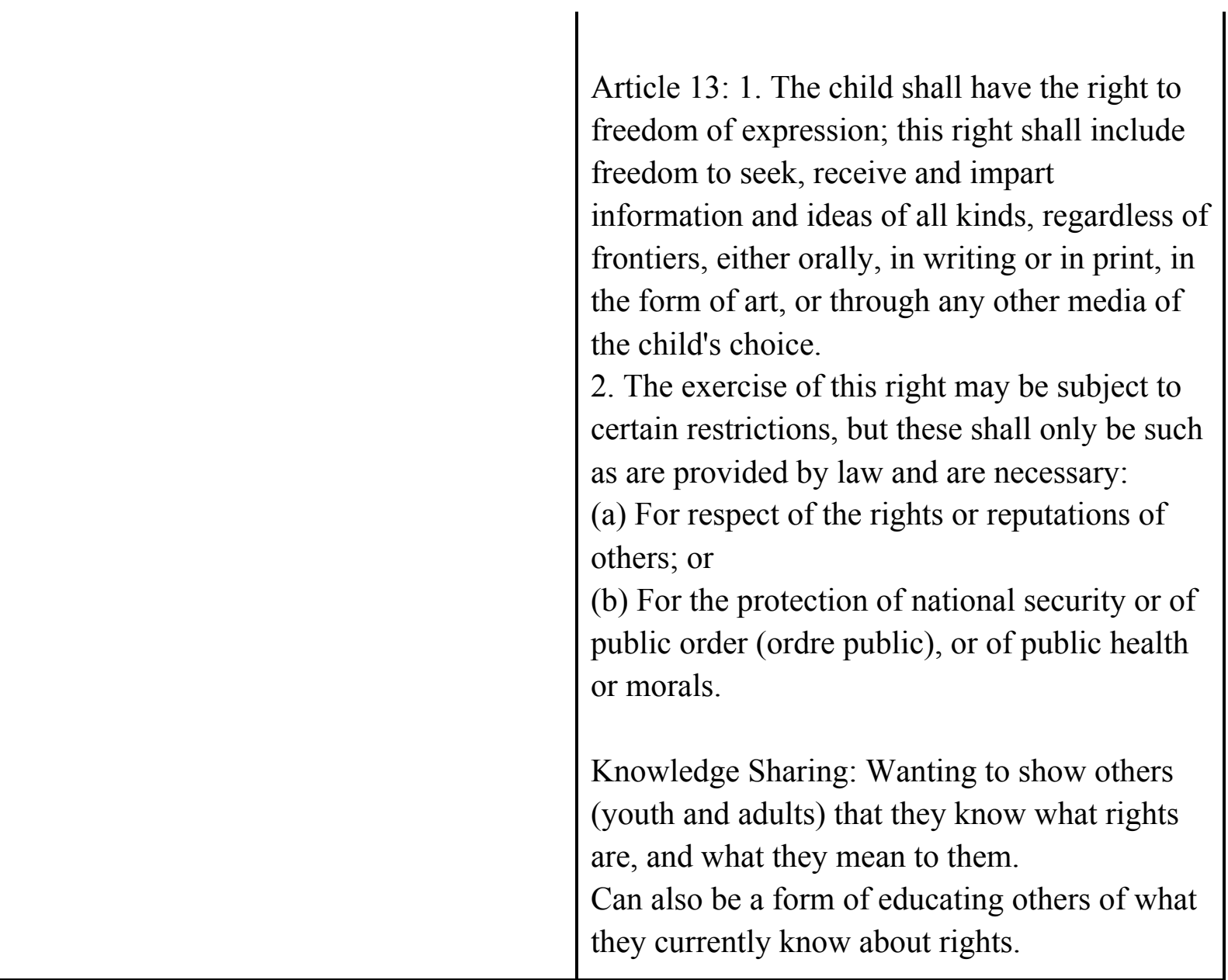

Source: (Robichaud et al., 2019)

Although children may not have explicitly stated their understanding of their rights, there were instances where children expressed their ideas around their rights through unique ways. Children in the 6- to 8-year-old group participated in an activity where they were asked about who they can depend on to help them understand their rights. One child did not explicitly answer the question; however, during another activity they drew a picture of their mother. When asked if they would like to share why they chose to draw their mother, the child stated that, "she makes food for him when he gets home from school" (Robichaud et al., 2019, p. 20). The child chose another means of expression to share this experience that demonstrates their mother protecting their right to an adequate standard of nutrition (UNCRC Article 27). The graduate students and youth facilitators involved in the event formed this conclusion because they expanded their definition of expression by considering that children might share their experiences around rights in forms of expression that are not vocal. 
During an activity called "wants versus needs" which was intended to create discussion around wants and needs in relation to rights, a 4-year-old child drew a date and explained that even though he does not enjoy eating dates, they considered the fruit a need because it is food. This expression helps us understand that children are capable of thinking about rights and that food is a necessity for an adequate standard of living, even if it is not their personal preference. This child's idea highlights the need to challenge the dominant discourse that views children, especially in their early years, to be self-centered and egotistic (Cordero Arce, 2012). How can we recognize non-normative expression? In realizing that children should have a range of media to express their ideas, thoughts, and beliefs (UNCRC Article 13), we must also consider the spaces children inhabit and how to best support their right to freedom of expression.

\section{Creating Spaces That Foster Children's Rights}

The UNCRC outlines that all children have the right to know their rights (UNCRC Article 42) and that they have a right to education that will help them develop respect for human rights and fundamental freedoms (UNCRC Article 29). According to Urinboyev, Wickenberg, and Leo (2016), children gain opportunities to learn about their rights through practices in their early learning programs. For instance, children, in collaboration with their early childhood educators, can create a charter of rights for their classroom. Instances where children are equally involved in the discussion and can express their ideas are beneficial for children in realizing their right to non-discrimination and participation because it actively invites and encourages them to enact their rights to participation.

During the STM: EC event, children in each group verbally expressed that they were responsible for upholding the rights of others. Children from the early childhood activity participated in a want versus need activity that invited a discussion about what they consider to be a want or a need in relation to rights. A sign was placed on either side of the room; one was labeled 'want' and the other was labeled 'need.' A facilitator held up pictures of objects or actions such as a dog or the act of sleeping, and the children were to think about whether the item or action was a need or a want and then they would run to the side of the room that represented their response. If they thought that the item was neither a need or a want they were asked to stay in the middle of the room. Following this activity, the children were offered materials to create 
their own image of a want or a need and were invited to share with the group if they wished. During the activity, children were asked what they thought they needed. One child responded by saying, "We need to be kind," and "We need to be careful." This child's view suggests that "we" (the children) as rights-holders also need to be kind to and careful with others and themselves.

The children in the 6- to 8-year-old group listened to Say Something, a story about children standing up for their rights and for the rights of others (Reynolds, 2019). When the facilitator asked the group what they could do when rights are being violated, one child responded, "say something." This suggests that children were thinking about the story and about speaking out and ensuring that other children's rights are protected. Similarly, in order to encourage children to think about what they know about their rights and what they learned about their rights from the workshop, the 6- to 8-year-old group of children were offered one piece of a wooden puzzle and invited to draw and/or write what they knew about their rights at the beginning of the workshop. Towards the end of the workshop, children were given the second piece and invited to draw and/or write what they had learned about their rights. When invited to share what they had to say about their rights puzzles, children stated they had the right to, "A mom and dad," "Have fun outside," "Live in a home," "I like to have mom and dad, home, sunlight," and "Have fun" (Robichaud et al., 2019, p. 21). These activities and discussions demonstrated that children are thinking about their rights and can express their thoughts and learnings when offered the appropriate materials.

The children in the 9- to 10-year-old group were offered a beach ball to write questions or comments on throughout the workshop. A facilitator posed the following question to the group, "What can we do to make people in our lives feel more included?" One child responded by saying, "We should help them, stand up for them, and make them feel better." The use of the collective "we" implies that all individuals have a responsibility to make others feel included. The children shared that this can be accomplished by "helping," "standing up," and "making them feel better." Similarly, when children were asked, "What should we do if we see someone being discriminated against?" a child responded that, "Other people should not try to make other people excluded." Children demonstrated that they are aware that it is everyone's responsibility to respect the right to non-discrimination by not excluding others (Robichaud et al., 2019). 
Children who participated in the STM: EC event demonstrated their understanding that they should know about their rights and that they are responsible for upholding the rights of others.

The 6- to 8-year-old group participated in an outdoor running activity called the 'Privilege' race. Initially found online by the graduate students, this racing activity was designed to explore the complexity of barriers and privileges that may contribute to discrimination in children's environments (Peter D, 2017). The original activity was altered to fit the theme of the right to non-discrimination. The children were provided with ten character cards to choose from and each character card had different symbols that represented various barriers and privileges that might affect the character's ability to participate in school, such as food, money, and transportation. All the children lined up at the starting line with their character cards and the youth facilitator read out a script of statements while holding up a visual of the symbol that the children were to look for on their card. For example, "if your character had breakfast (egg symbol on the card) this morning, come forward two moves." The youth facilitator continued to call out symbols until finished. At the end of the race, the children were asked to look around them and notice which characters were ahead of other characters. The facilitators then reminded the group that although education is a right, barriers exist that discriminate against some children in having access to education. Through this activity, children were invited to experience discrimination by taking on the role of a character and role-playing in a safe space. Comments during, and discussions after, the activity lead us to understand that children were able to express their views around different rights and forms of discrimination. For example, when some children had the lunch symbol and some did not, one child yelled out, "we can share." They also acknowledged hardships some children face as one child stated, "my character had to go a long distance to go to school." This outdoor activity demonstrated that children can explore complex topics and share their thoughts and views.

\section{Families as Advocates for Children's Rights}

The family members of the children who participated in the STM: EC event were invited to join and share their thoughts and experiences in relation to children's rights by attending a workshop specifically planned for them (Robichaud et al., 2019). Throughout the workshop, family members shared their knowledge on children's rights and, more specifically, their understanding of children's right to non-discrimination. The family group engaged in many 
valuable discussions by participating in meaningful activities. Throughout the event, all family members contributed different perspectives to the conversation based on their experiences and knowledge unique to their own family. This section presents the insightful messages that emerged from the discussions (Robichaud et al., 2019).

Adult family members often assume a position of power over children, typically due to their role in ensuring that children's rights are protected and met (Ruck, Peterson-Badali \& Day, 2002). Given that learning occurs within the home in a family environment, family perspectives are crucial (Howe \& Covell, 2007) as their actions and thoughts around children's rights have significant implications (Ruck, Peterson-Badali, \& Day, 2002). Family beliefs and perspectives may affect the way children view discrimination and, in turn, this will play a role on how children understand their right to non-discrimination. Therefore, it was important for family members to be included in the STM events as their views and beliefs will impact children and youth.

\section{Incorporating Family Perspectives on Children's Rights to Non-}

\section{Discrimination}

When adults were asked when they can help children enact their rights, one adult participant replied by saying that, "the sooner the better" (Robichaud et al., 2019, p. 28). This statement became significant as it reflected how adults are eager to support children in learning about their rights to non-discrimination and that their perspectives should be incorporated in these related discussions. In one activity, the family members were asked to note their thoughts and feelings regarding children's right to non-discrimination. During this activity, they expressed that adults can encourage children to enact their rights by reading books related to children's rights, challenging discrimination, promoting learning about their rights through the media, and by modifying the ways in which they talk to children about their rights (Robichaud et al., 2019). Families further shared that critical thinking is a way in which children can enact their right to non-discrimination. According to a participant from the family group, teaching critical thinking to children can help encourage them to enact their rights in the home, school, and community (Robichaud et al., 2019). They also suggested that children can be encouraged to enact their right to non-discrimination at school by questioning authority figures. They should also understand their rights and have the resources needed to advocate for their rights and needs (Robichaud et al., 2019). In the community, family members shared that the right to non-discrimination can be 
supported by "respecting others, celebrating human difference, [talking] about and [normalizing] differences and standing up for themselves and others" (Robichaud et al., 2019, p. 32). On a global level, families noted that children can challenge complicated intersections and social issues such as discrimination, educational and human rights. Children should advocate for issues that matter to them, and be aware and exposed to various cultures and languages (Robichaud et al., 2019).

During the workshop, facilitators used 'polleverywhere.com' and asked participants to submit a word or phrase that they thought would encourage children to exercise their right to non-discrimination. Prominent words that came up through this word cloud included “children/child" "voice" "freedom" and "citizen" (Robichaud et al., 2019, p. 34). A discussion about the importance of children's voices emerged as the main theme that was being discussed through this activity. Families noted the significance of finding opportunities for children to express their views while including them in the process of decision-making (Robichaud et al., 2019). This ultimately supports children in developing autonomy and a lifelong skill of being aware that they have the ability and confidence to think and make choices for themselves. When families ensure that children's voices are heard and valued, it promotes the idea that children are active learners, and are constantly engaged in their own learning. This further helps children understand that adults view them as knowledgeable about their rights and specifically their right to non-discrimination.

\section{Ideas for Future Workshop Planning}

The STM: EC event challenged us to learn more about children's understanding of their rights and encouraged us to think about recommendations for future STM events. These recommendations are based on the STM: EC event, conversations with families, the STM: EC report (Robichaud et al., 2019) and children's rights in general. Recommendations include suggestions that future STM events continue to involve young children, consider non-classroom locations, and continue to provide open-ended materials, resources, and mediums.

The first recommendation is to expand STM: EC with attention to including diverse communities. Throughout this article, we highlight how various activities followed by discussions showed that young children can form views and are capable of expressing those views. As this STM event was one of the first to include young children, we suggest that future 
STM events consider the great benefits discussed in this article and continue to invite young children from diverse communities to participate in future events.

The second recommendation is that STM: EC take place in outdoor settings. This was based on our observations of children who participated in an outdoor activity, as there seemed to be a greater sense of comfort once they returned indoors, indicating that the outdoors may have been a positive environment for children. Therefore, we recommend that future STM workshops consider offering outdoor activities for all age groups. Additionally, introducing the event outdoors may be beneficial in creating greater comfort for children, in comparison to the standard classroom environment that may potentially be associated with previous rights violations (Goodman \& Cook, 2019) and initially create discomfort.

The third recommendation is to include open-ended materials and opportunities for creative expression. The UNCRC states that children have the right to freedom of expression through the use of various forms of communication (United Nations General Assembly, 1989, Article 13). The activities held in the STM: EC event included open-ended materials for creative expression (i.e., markers, pompoms, plasticine, wooden puzzle pieces), rights based books such as I Have the Right to Be a Child, (Serres, 2009) and Say Something (Reynolds, 2019), and movement activities such as the "wants" versus "needs" activity and the privilege race. The event demonstrated that providing a range of materials and activities encourages children to express themselves using a method that they find best fitting. We learned that children's expressions may not be explicit as children express their understandings and thoughts about their rights using different modes.

\section{Conclusion}

The STM: EC workshop was part of a three-site pilot that used the STM model that is usually targeted to 8- to- 18-year-olds, and tailored it to work with children ages 3 to 7 . STM recognizes the extent to which children understand their rights and how they are able to effectively express their views and experiences using unique forms. STM also critically considers diminishing the adult role and supports youth in facilitating the workshops. As authors of this article who also co-developed the STM: EC event, we reflected on our learnings from the event and drew on children's and families' expressions as documented in the report (Shaking the Movers: Early Childhood Report, 2019). Raising discussions and evidence to suggest that when offered the appropriate resources and opportunities, children are capable of forming their views 
around their rights and are able to express those views. The STM: EC event serves as a reminder that children are knowledgeable of their rights and have much to contribute as rights holders. Additionally, STM: EC demonstrates the importance of creating and mindfully planning spaces in which children can safely explore their rights. We must continue to make such spaces available for young children to encourage them to learn about and enact their rights. Creating and advocating for such spaces encourages young children to learn about and enact their rights.

\section{Acknowledgements}

We would like to acknowledge the contributions of those involved in creating and participating in carrying out the STM: EC event. The STM: EC event and this article could not possibly have been accomplished without the following people and funders: the children, their families and youth facilitators involved in STM: EC 2019; and Dr. Aurelia Di Santo: Children's Rights course instructor who was involved in managing, supervising, and planning the STM: EC event, together with the MA ECS students and provided support and feedback for the preparation of this article. Funders for this event are: the Landon Pearson Resource Centre for the Study of Childhood and Children's Rights at Carleton University; The Muttart Family Foundation; and Ryerson University, School of Early Childhood Studies. The Masters of Arts in Early Childhood Studies Students who participated in STM: EC are: Kristen Arts, Chantal Carneiro, Jacqueline Da Costa, Rhydima Deshpande, Nicole Dulysh, Amanda Gleed, Erin Harvey, Jenny Huang, Madeleine Hutchison, Amrita Maharajh-Gajadhar, Sierra Miller, Sophia Mohamed, Nancy Santos, Amy Schoeppich, Leah Shoemaker, Shaamini Sooriyakumar, Chloe Waters, Vincent 


\section{References}

Albanese, P. (2009). Children in Canada Today. Don Mills, ON: Oxford University Press. 18-36.

Bohman, J. (2005). Critical Theory. The Stanford Encyclopedia of Philosophy (Spring 2005 Edition), Edward N. Zalta (ed.).

Cordero Arce, M. (2012). Towards an emancipatory discourse of children's rights. International Journal of Children's Rights, 20(3), 365-421.

Covell, K., McNeil, J. K., \& Howe, R. B. (2009). Reducing teacher burnout by increasing student engagement: A children's rights approach. School Psychology International, 30(3), 282-290.

Dunhill, A. (2018). Does teaching children about human rights, encourage them to practice, protect and promote the rights of others? Education 3-13, 46(1), 16-26. doi:10.1080/03004279.2016.1165717

Goodman, J. F., \& Cook, B. I. (2019). Shaming school children: A violation of fundamental rights? Theory and Research in Education, 17(1), 62-81. https://doi.org/10.1177/1477878518817377

Harcourt, D. \& Conroy, H. (2011). Informed consent: Processes and procedures seeking research partnerships with young children. In D. Harcourt, B. Perry and T. Waller (eds.). Researching young children's perspectives: The ethics and dilemmas of educational research with children. 38-51. London \& New York: Routledge.

Howe, R. B. \& Covell, K. (2007). Empowering Children: Children's Rights Education as a Pathway to Citizenship. Toronto: University of Toronto Press.

Lansdown, G., Jimerson, S. R., \& Shahroozi, R. (2014). Children's rights and school psychology: Children's right to participation. Journal of School Psychology, 52(1), 3-12. https://doi.org/10.1016/j.jsp.2013.12.006

Matthews, S. H. (2007). A window on the 'new' sociology of childhood. Sociology Compass, $1(1), 322-334$.

Pearson, L., \& Collins, T. (2011). Shaking the Movers: A Model for Collaborative Consultation with Children and Youth on Public Policy. Retrieved from https://carleton.ca/landonpearsoncentre/wp-content/uploads/Shaking_the_Movers_A_Mo del_for_Collabora.pdf 
Peter D. (2017, Oct. 3). Life of privilege explained in a \$100 race - please watch to the end [video file]. Retrieved from https://www.youtube.com/watch?v=4K5fbQ1-zps

Reynolds, H. P. (2019). Say Something. New York: Orchard Books, an imprint of Scholastic Inc. Robichaud, B., Leeder, M., Di Santo, A., \& Leeder, C. (2019). Shaking the Movers: Early Childhood. Landon Pearson Resource Centre for the Study of Childhood and Children's Rights. Retrieved from https://carleton.ca/landonpearsoncentre/wp-content/uploads/2019-Shaking-the-Movers-E arly-Childhood-Ryerson-U-Toronto.pdf

Robinson, C. (2011). Children's rights in student voice projects: Where does the power lie? Education Inquiry, 2(3), 437-451. doi:10.3402/edui.v2i3.21993

Ruck, M. D., Peterson Badali, M., \& Day, D. M. (2002). Adolescents' and mothers' understanding of children's rights in the home. Journal of Research on Adolescence, 12(3), 373-398. doi:10.1111/1532-7795.00038

Sebba, J., \& Robinson, C. (2010). “Evaluation of UNICEF UK's Rights Respecting School Award." Retrieved from http://www.unicef.org.uk/Documents/Education-Documents/RRSA_Evaluation_Report. Pdf.

Serres, A. (2009). I Have the Right to Be a Child. Groundwood Books.

Shier, H. (2010). Children as public actors: Navigating the tensions. Children \& Society, 24(1), 24-37.

Stoecklin, D. (2013). Theories of action in the field of child participation: In search of explicit frameworks. Childhood, 20(4), 443-457.

United Nations General Assembly. (1989). Convention on the Rights of the Child, United Nations, Treaty Series, 1577, 3. Retrieved from https://www.refworld.org/docid/3ae6b38f0.html

United Nations Human Rights. (2019). UN treaty body database. Retrieved from https://tbinternet.ohchr.org/_layouts/15/TreatyBodyExternal/Treaty.aspx?CountryID=31 $\&$ Lang $=\mathrm{EN}$

Urinboyev, R., Wickenberg, P., \& Leo, U. (2016). Child rights, classroom and school management: A systematic literature review. The International Journal of Children Rights, 24. 499-521. 10.1163/15718182-02403002. 